\title{
Synthesis and Physicochemical Characterization of Chemically Modified Chitosan by Succinic Anhydride
}

\author{
Karine Gargioni Pereira Correa de Mello*, Leandra de Cássia Bernusso, Ronaldo \\ Nogueira de Moraes Pitombo and Bronislaw Polakiewicz \\ Departamento de Tecnologia Bioquímico-Farmacêutica; Faculdade de Ciências Farmacêuticas; Universidade de \\ São Paulo; Av. Lineu Prestes, 580; Bloco 16; Cidade Universitária; bronipol@usp.br; 05508-900; São Paulo - SP - \\ Brasil
}

\begin{abstract}
The N-succinil-chitosan is a chemically modified derivative of the biopolymer chitosan. The succinic anhydride attached to the free amino groups presented along the chitosan's polymer chain imparts to the molecule different physicochemical properties not exhibited before the modification. These chemical modifications enhance chitosan's solubility in slightly acid, neutral and alkaline media. These properties are related to the long alkyl chains attached to hydrophilic parts. In this case the hydrophilic part of D-glucosamine promotes stronger interactions with the water molecules, and consequently, enhances the solubility of the chitosan polymer. Non-modified free chitosan is soluble only in acidic medium $(\mathrm{pH} \leq 5.5)$. These modifications made possible new applications of chitosan in biotechnological area since the solubility in neutral or slightly alkaline solutions is very important in a biological field.
\end{abstract}

Key words: N-succinil-chitosan, succinic anhydride, biopolymer, solubility

\section{INTRODUCTION}

Chitin is a biopolymer similar to cellulose and quite abundant in nature. It is extracted mainly from crustaceous skin or shells. (Singla, 2001; Khan, 2002; Tangpasuthadol, 2003). Due to the natural origin of chitin, different variants are found in environment. In addition, when chitin is submitted to different chemical processes, a series of polymers varying in the degree of deacetylation (DD), molecular weight (MW), viscosity, pKa, etc, may be generated (Chatelet, 2000; Canella, 2001; Singla, 2001). Chitosan is a natural polysaccharide composed of $\beta(1-4)$-D-glucosamine units originated from the total or partial deacetilation of chitin in alkaline solutions (Singla, 2001; Dee,
2004). It is soluble in acid medium $(\mathrm{pH}<5.5)$ due to the presence of free amino groups along the polymer chain. The presence of these amino groups allows the synthesis of different chitosan derivatives (Khan,2002; Franco, 2004). The purpose of this study was to synthesize a $\mathrm{N}$ succinil-chitosan derivative based on a methodology proposed by Yamagushi et al, 1981 with some modifications (Yamagushi,1981).

\section{MATERIAL AND METHODS}

Chitosan samples were obtained from shrimp's shells and purchased from Farma Service

\footnotetext{
${ }^{*}$ Author for correspondence
} 
Bioextract (São Paulo, Brasil). All chemicals were of analytical grade.

\section{Sample preparation}

Two samples of N-succinil-chitosan were prepared by reaction of chitosan (Chit) with succinic anhydride at $1: 1 \mathrm{w} / \mathrm{w}(0.06: 0.01, \mathrm{~mol} / \mathrm{mol})$ and $1: 3$ $\mathrm{w} / \mathrm{w}(0.06: 0.03 \mathrm{~mol} / \mathrm{mol})$ proportions named as CS1:1 and CS1:3, respectively. These molar quantities of chitosan/anhydride were smaller than what it was suggested in the original work of Yamagushi et al. (1981), who used an excess of anhydride (16,4moles/amino group). The sample was precipitated with ethanol, not methanol as the authors proposed, without yield losses. Moreover, the previous solubilization of succinic anhydride in acetone was substituted by direct addition of the succinic anhydride to the reactional medium.

\section{Sample characterization}

The solubility of chitosan and its synthesized derivative was evaluated at different $\mathrm{pH}$ : acid ( $\mathrm{pH}=4.0 ; \quad 3 \% \quad \mathrm{CH}_{3} \mathrm{COOH}$ solution), neutral $(\mathrm{pH}=7.0$, water) and alkaline medium $(\mathrm{pH}=10.0$; $0.1 \mathrm{~mol} \mathrm{~L}^{-1} \mathrm{NaOH}$ solution) at room temperature $\left(25^{\circ} \mathrm{C}\right)$. Qualitative observations of the samples submitted to the solubilization tests were registered after 1,5 and 10 hours.

The deacetylation degree (DD) of chitosan and its derivative was determined by infrared (IR) spectroscopy and ninhydrin titration The substitution degree (SD) was determined using the same techniques. (Curotto, 1999; Canella, 2001; Khan, 2002). The spectra of chitosan sample (in the forms of $\mathrm{KBr}$ disks) were obtained using an IR
Instrument (Bomem MB-100 FTIR, Germany) with a frequency range of $4000-400 \mathrm{~cm}^{-1}$. The degree of deacetilation of the chitosan sample by IR spectroscopy was calculated using the equation proposed by Domszy and Roberts that is given below:

$$
\mathrm{DD}=100-\left[\left(\mathrm{A}_{1665} / \mathrm{A}_{3450}\right) \times 100 / 1.33\right.
$$

where $\mathrm{A}_{1665}$ and $\mathrm{A}_{3450}$ were the absorbance at $1655 \mathrm{~cm}^{-1}$ of the amide-I band as a measure of the $\mathrm{N}$-acetyl group content and $3450 \mathrm{~cm}^{-1}$ of the hydroxyl band as an internal standard to correct for film thickness or for differences in chitosan concentration powder form. The factor ' 1.33 ' denoted the value of the ratio of $\mathrm{A}_{1665} / \mathrm{A}_{3450}$ for fully $\mathrm{N}$-acetylated chitosan. It was assumed that the value of this ratio was zero for fully deacetylated chitosan.

The hygroscopic degree was measured under vacuum in $90.70 \%$ humidity dessicators containing $\mathrm{BaCl}_{2}$ salt. Samples were previously freeze-dried during $24 \mathrm{~h}$, accurately weighted and placed in the dessicator. The measurements were done in $1 \mathrm{~h}$ intervals for $5 \mathrm{~h}$, until constant weight for chitosan and its derivative was reached.

\section{RESULTS AND DISCUSSION}

The solubility measurements are shown in Table 1 for three different $\mathrm{pHs}$. Chit was perfectly soluble in acetic acid solution but precipitated at neutral and alkaline solutions.

$\underline{\text { Table } 1 \text { - Solubility tests of Chit and modified chitosans CS1:1 and CS1:3 in different solutions and pHs. }}$

\begin{tabular}{lccc} 
& & Solubility & \\
\cline { 2 - 5 } & $\mathbf{p H = 4 . 0}$ & $\mathbf{p H = 7 . 0}$ & $\mathbf{p H = 1 0 . 0}$ \\
\hline Chit & ++++ & - & - \\
SC1:1 & ++ & ++ & +++ \\
SC1:3 & - & ++ & ++++ \\
\hline
\end{tabular}

This was expected due to the presence of amino groups along the polymer chain which were protonated under low $\mathrm{pH}$. SC1:1 became partially solubilized in the entire $\mathrm{pH}$ range due to the increasing substitution of the amino groups by carboxylic groups, which became negatively charged above $\mathrm{pH}$ 6.0. The highly substituted $\mathrm{SC} 1: 3$ appeared insoluble in $\mathrm{pH} 4.0$ due to the predominance of carboxylic groups compared to amino groups but totally solubilized at high $\mathrm{pH}$, where the complete dissociation of carboxylic acid groups occured.

Deacetylation degree (DD) of original chitosan sample was determined to verify how many amino groups were available to react with succinic anhydride. Substitution degree (SD) was determined for the modified samples. In Figure 1 both results of DD for Chit and SD for SC1:1 and 
$\mathrm{SC} 1: 3$ are shown. It was possible to verify that the initial Chit presented a DD of $45 \%$ while the substituted samples, SC1:1 and SC1:3, presented a SD of 10 and $20 \%$, respectively. The increased substitution of amino groups by carboxylic groups was directly related to the increase in solubility related previously. The relatively low substitution degree obtained for both modified samples could be explained in part due to the hydrolysis of the reactant..

In Fig. 2 the capacity of the samples to absorb humidity at room temperature are shown. It was observed that the modified samples absorbed more humidity than Chit.

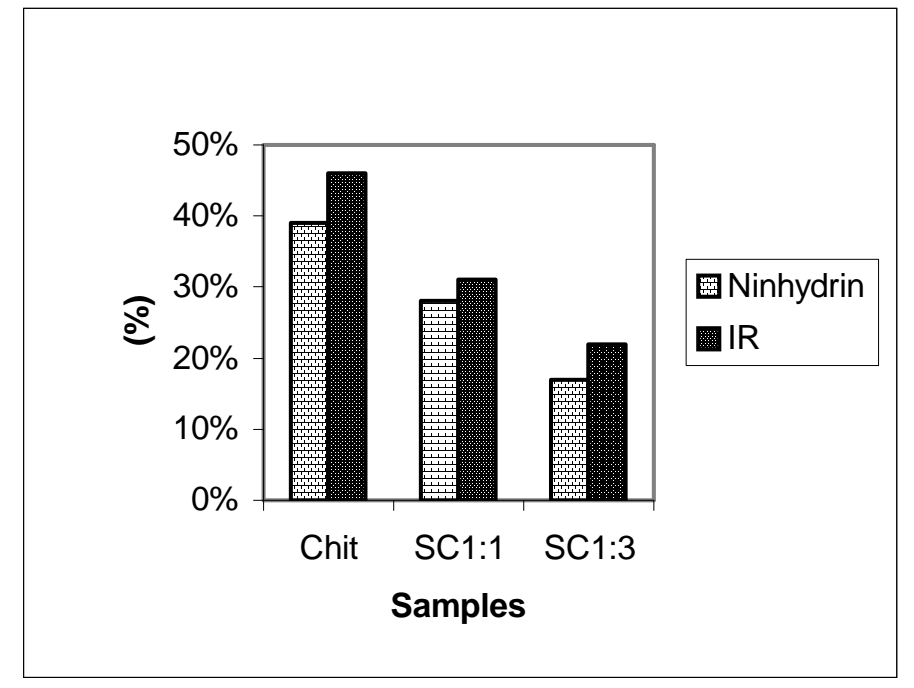

Figure 1 - Deacetilation of Chit and substitution degree of modified samples determined by ninhydrin titration and infrared spectroscopy

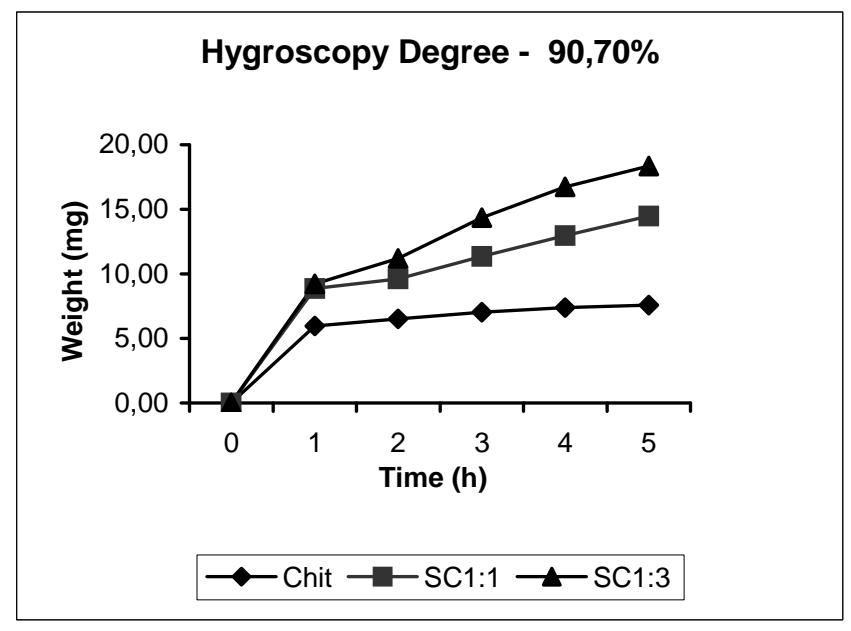

Figure 2 - Hygroscopy degree of the modified Chitosan samples in $90.70 \%$ humidity environment.

All samples absorbed more humidity in the first hour followed by shorter increase in the next $5 \mathrm{~h}$ when the weight becomes constant. Among all samples, SC1:3, which was the most substituted sample, presented a larger hygroscopic degree as a function of time and temperature. 


\section{CONCLUSION}

The different physicochemical properties determined in this study indicated that $\mathrm{N}$-succinicchitosan could be applied in many biotechnological fields. The molar quantities of chitosan/anhydride used in these study were quite lower than what it was done in the original Yamagushi's 1981 work and, the modifications introduced in the sample preparation resulted in optimization of the process, economy of reactants without losses of physicochemical properties. The solubility of substituted chitosan samples in neutral and alkaline media increase the possibility of use in cosmetics and pharmaceutical. The hygroscopic capacity of the modified samples could be useful to film formation, to membranes formulated for wound healing and as additive in cosmetics and toiletries.

\section{ACKNOWLEDGEMENTS}

The authors thank CAPES for the financial support and Farma Service Bioextract for providing chitosan samples.

\section{RESUMO}

A N-succinil-quitosana é um derivado quimicamente modificado do biopolímero quitosana. A inserção de substituintes de anidrido succínico nas aminas protonadas presentes ao longo da cadeia do polímero quitosana, conferem diferentes características físico-químicas a molécula de quitosana.

Esta modificação química, possibilitou à quitosana, solubilidade em $\mathrm{pHs}$ que variam do ácido (2.0 a 3.0) até alcalino (13.0 a 14.0). Estas propriedades são atribuídas ao alongamento da cadeia alquílica, que afasta a parte hidrofílica da cadeia fechada da D-glicosamina, facilitando o acesso da água, a qual irá estabelecer uma interação mais forte com a molécula de quitosana. Esta propriedade não está presente em amostras de quitosana pura, a qual sabe-se que solubiliza-se apenas em pH abaixo de 5.5. Estas modificações na quitosana possibilitam novas aplicações na área de biotecnologia, uma vez que a solubilidade em meio neutro e levemente alcalino é importante na área biológica.

\section{REFERENCES}

Canella, K. M. N. and Garcia, R. B. (2001), Caracterização de Quitosana por Cromatografia de Permeação em Gel - Influência do Método de preparação e do Solvente. Química Nova, 24 : (10, 13-17.

Chatelet, C.; Damour,O. and Domard, A. (2001), Influence of the degree of acetylation on some biological properties of chitosan films. Biomaterials, 22, 261-268.

Curotto, E. and FresiA, A. (1993), Quantitative determination of chitosan and the percent age of free amino groups. Analytical Biochemistry, 211, 240-241.

Dee, J. D.; Rhode, O. and Wachter, R. (2001), Chitosan-Multi-functional marine polymer. Cosmetics and Toiletries, 116 : (2), 39-42.

Domszy, J. G. and Roberts, G. A. F. (1978), In: Muzzarelli, R. A. A. and Pariser, E. R. (Eds.). Proceedings of the first International Conference on chitin/chitosan. MIT Sea Grant Report 78-7. pp 421.

Franco, L. O.; Stamford, M. T. C.; Stamford, N. P. and Takaki, G. M. C. (2004), Cunningamella elegans (IFM46109) como fonte de quitina e quitosana. Revista Analytica, 14, 40-44.

Khan, T. A.; Peh, K. K. and Ching, H. S. (2002), Reporting degree of deacetilation values of chitosan: the influence of analytical methods. Jounal of Pharmaceutical Science, 5 : (3), 205-212.

Prashanth, K. V.; Kittr, F. S. and Tharanathan, R. N. (2002), Solid state strcture of chitosan prepared under different N-deacetylating conditions. Carbohydrate Polymers, 50, 27-33.

Singla, A. K. and Chawla, M. (2001), Chitosan: some pharmaceutical and biological aspects - an update. Journal of Pharmacy and Pharmacology, 53, 10471067.

Tangpasuthadol, V.; Pongchaisirikul, N. and Hoven, V. P. (2003), Surface modification of chitosan films. Effects of hydrophobicity on protein adsorption. Carbohydrate Research, 338, 937-942.

Yamaguchi, R.; Arai, Y. and Itoh, T. (1981), Preparation of partially N-succinilated chitosans and their cross-linked gels. Carbohydrate Research, 88, 172-175. 